\title{
Identifikasi Struktur Perlapisan Bawah Permukaan Berdasarkan Analisis Gelombang Geser Di Kecamatan Palu Barat
}

\section{(Identification of subsurface structure based on the shear wave analysis in West Palu subdistrict)}

\author{
Musrifah Am Tayeb*), Rustan Efendi, Sandra Kasim \\ Program Studi Fisika Jurusan Fisika FMIPA, Universitas Tadulako
}

\begin{abstract}
Research using microtremor refraction method has been conducted in the district of Palu Barat by recording the wave propagation under the surface. The purpose of this study was to identify the structure of the subsurface layering based on the analysis of shear waves using microtremor refraction. Data processing was performed using 2 programs, which uses Surface Wave Analysis Wizard program and WaveEq program (Surface Wave Analysis). The results of the estimated value of shear wave velocity on the field of SMA 4 is ranges between $165 \mathrm{~m} / \mathrm{s}$ to $670 \mathrm{~m} / \mathrm{s}$. to the field of agung mosque ranges between $235 \mathrm{~m} / \mathrm{s}$ to $735 \mathrm{~m} / \mathrm{s}$, for the field of lasoso range $100 \mathrm{~m} / \mathrm{s}$ to $565 \mathrm{~m} / \mathrm{s}$, for the field of durian street ranged from $335 \mathrm{~m} / \mathrm{s}$ to $595 \mathrm{~m} / \mathrm{s}$, for the field of anggur street ranged between $215 \mathrm{~m} / \mathrm{s}$ to $670 \mathrm{~m} / \mathrm{s}$, for the field of gajah mada street ranged between $305 \mathrm{~m} / \mathrm{s}$ to $640 \mathrm{~m} / \mathrm{s}$. The shear wave velocity values show on wesk Palu Barat district is dominated by rock alluvium, saturated sand and clay sand.
\end{abstract}

\section{Key words: Microtremor Refraction (ReMi), Shear Waves, Rock Structure}

\begin{abstract}
ABSTRAK
Penelitian dengan metode refraksi mikrotremor telah dilakukan di Kecamatan Palu Barat dengan merekam penjalaran gelombang yang terjadi di bawah permukaan. Adapun tujuan dari penelitian ini untuk mengidentifikasi struktur perlapisan bawah permukaan berdasarkan analisis gelombang geser dengan menggunakan metode refraksi mikrotremor. Pengolahan data dilakukan dengan menggunakan 2 program yaitu menggunakan program Surface Wave Analysis Wizard dan program WaveEq (Surface Wave Analysis). Hasil estimasi nilai kecepatan gelombang geser pada lapangan SMA 4 berkisar antara $165 \mathrm{~m} / \mathrm{s}$ sampai 670 $\mathrm{m} / \mathrm{s}$, untuk lapangan masjid agung berkisar antara $235 \mathrm{~m} / \mathrm{s}$ sampai $735 \mathrm{~m} / \mathrm{s}$, untuk lapangan bola lasoso berkisar antara $100 \mathrm{~m} / \mathrm{s}$ sampai $565 \mathrm{~m} / \mathrm{s}$, untuk lapangan bola durian berkisar antara $335 \mathrm{~m} / \mathrm{s}$ sampai $595 \mathrm{~m} / \mathrm{s}$, untuk lapangan bola anggur berkisar antara $215 \mathrm{~m} / \mathrm{s}$ sampai $670 \mathrm{~m} / \mathrm{s}$, untuk lapangan bolagajah mada berkisar antara $305 \mathrm{~m} / \mathrm{s}$ sampai $640 \mathrm{~m} / \mathrm{s}$. Nilai kecepatan gelombang geser tersebut menunjukan bahwa pada Kecamatan Palu Barat didominasi oleh batuan aluvium, pasir tersaturasi dan lempung pasiran.
\end{abstract}

Kata Kunci: Refraksi Mikrotremor (ReMi), Gelombang Geser, Struktur Batuan. 


\section{LATAR BELAKANG}

Pembangunan permukiman di Kota Palu akhir-akhir ini mengalami peningkatan yang sangat pesat, tak terkecuali di Kecamatan Palu Barat. Hal ini merupakan suatu usaha untuk meningkatkan berbagai indikator ekonomi, pendidikan, perkantoran dan kesehatan dengan dukungan ketersediaan sarana dan prasarana. Pembangunan yang baik seharusnya mempertimbangkan keadaan geologi wilayahnya agar terhindar dari ancaman bencana. Secara geologis, Kota Palu dilintasi oleh Sesar Palu-Koro, sesar ini merupakan salah satu sesar dengan pergerakan yang cukup aktif (Abdullah, 2005). Keadaan sesar aktif tersebut bisa memicu terjadinya gempa tektonik yang mengakibatkan kerusakan pada bangunan.

Kerusakan bangunan akibat gempa di Kota Palu disebabkan karena banyak bangunan yang didirikan tanpa mempertimbangkan struktur lapisan bawah permukaan. Seperti yang terjadi di Kelurahan Ujuna yang mana mengakibatkan keretakan bagian depan masjid, perumahan warga dan tanggul sungai Palu. Berdasarkan uraian di atas, dengan pertimbangan bahwa Kecamatan Palu Barat merupakan wilayah dengan tingkat pembangunan yang relatif tinggi, sehingga diperlukan informasi-informasi struktur perlapisan bawah permukaan bumi.

Salah satu metode geofisika yang dapat digunakan untuk melihat struktur perlapisan bawah permukaan adalah metode seismik. Metode seismik dikategorikan dalam 2 bagian yaitu seismik refraksi (seismik bias) dan seismik refleksi (seismik pantul). Metode yang dibahas dalam penulisan ini hanya mencakup metode seismik refraksi mikrotremor. Dalam metode seismik refraksi, yang diukur adalah waktu tempuh gelombang dari sumber menuju geophone. Metode ini telah dipergunakan untuk mendeteksi perlapisan dangkal menggunakan penjalaran gelombang geser dan hasilnya cukup memuaskan (Uswatun, 2012). Analisis Gelombang geser dengan menggunakan metode ini diharapkan dapat menjelaskan kondisi struktur perlapisan bawah permukaan di Kecamatan Palu Barat.

\section{METODE PENELITIAN}

Penelitian dilakukan di 6 lokasi dengan masing-masing lokasi diukur untuk 1 lintasan. Lokasi penelitian berada di Kecamatan Palu Barat, Posisi pengukuran berada pada ketinggian 4 meter sampai 31 meter di atas permukaan laut (Gambar 14).

\section{Identifikasi Struktur Perlapisan Bawah Permukaan Berdasarkan Analisis Gelombang Geser Di Kecamatan Palu Barat}


Pengambilan data menggunakan metode seismik, menggunakan beberapa peralatan sebagai berikut :

1. Pasi MD 16S24-P untuk melihat perambatan gelombang yang terjadi di bawah permukaan.

2. Detektor geophone 24 channel sebagai sensor untuk mendeteksi perambatan gelombang di bawah permukaan.

3. Kabel penghubung (trigger, extension, konektor).

4. Sumber arus $(a c c u)$.

5. Global Positioning System (GPS) berfungsi untuk menentukan posisi setiap geophone.

6. Kompas Geologi untuk mentukan arah bentangan.

7. Meteran untuk mengukur jarak antar geophone dan mengukur jarak tembak.

8. Palu Geologi.

9. Alat tulis menulis.

Pengolahan data dilakukan dengan langkah-langkah sebagai berikut:

1. Data yang diperoleh dalam domain waktu diubah dalam domain frekuensi dengan menggunakan transformasi Fourier, sehingga didapatkan kurva dispersi menggunakan Software Wafe Analysis Wizard (Susy dkk., 2009).

2. Hasil dari kurva dispersi akan didapatkan informasi tentang kualitas data dan kecepatan fase sebagai fungsi frekuensi yang diperoleh dari fase Cross Power Spektrum.

3. Melakukan inversi dari kurva dispersi untuk mendapatkan profil kecepatan gelombang geser dari lapisan bawah permukaan dengan menggunakan Software WaveEq. Selanjutnya menganalisis kecepatan gelombang geser untuk mengetahui struktur perlapisan batuan bawah permukaan berdasarkan nilai kecepatan gelombang geser yang ada pada Tabel 1 .

Tabel 1. Nilai Kecepatan Gelombang Sekunder dan Densitas Berdasarkan Jenis Material (Sumber: Widodo, 2012)

\begin{tabular}{|c|c|c|c|c|}
\hline \multirow{2}{*}{ No } & \multirow[t]{2}{*}{ Material } & \multicolumn{2}{|c|}{ Kecepatan $(\mathbf{m} / \mathbf{s})$} & \multirow{2}{*}{$\begin{array}{l}\text { Densitas } \\
(\mathrm{g} / \mathrm{cm} 3)\end{array}$} \\
\hline & & $\begin{array}{c}\text { Wave } \\
\text { (P) }\end{array}$ & $\begin{array}{c}\text { Wave } \\
\text { (S) }\end{array}$ & \\
\hline 1 & Beton & 3600 & 2000 & $\begin{array}{l}2350- \\
2450\end{array}$ \\
\hline 2 & $\begin{array}{c}\text { Granit } \\
\text { Dolerit } \\
\text { Gabro } \\
\text { Andesit } \\
\text { Basal }\end{array}$ & $\begin{array}{l}4500- \\
6500 \\
3500- \\
6700 \\
4500- \\
7000 \\
4500- \\
6500 \\
5000- \\
7000\end{array}$ & $\begin{array}{l}3500- \\
3800 \\
2960- \\
3450 \\
2700- \\
3500 \\
2440- \\
3500 \\
3600- \\
3700\end{array}$ & $\begin{array}{l}2530- \\
2450 \\
2800- \\
3000 \\
2720- \\
3000 \\
2500- \\
2800 \\
2210- \\
2770\end{array}$ \\
\hline
\end{tabular}

\section{Identifikasi Struktur Perlapisan Bawah Permukaan Berdasarkan Analisis Gelombang Geser Di Kecamatan Palu Barat}




\begin{tabular}{|c|c|c|c|}
\hline \begin{tabular}{|c} 
Pasir (Tidak \\
tersaturasi) \\
Pasir \\
(Tersaturasi) \\
Lempung \\
Aluvium
\end{tabular} & $\begin{array}{l}200- \\
1000 \\
800- \\
2000 \\
1000- \\
2500 \\
1500- \\
2500\end{array}$ & $\begin{array}{l}80-400 \\
320- \\
8800 \\
\\
400- \\
1000 \\
\\
120- \\
3600\end{array}$ & $\begin{array}{l}2000- \\
2600 \\
2500- \\
2800\end{array}$ \\
\hline
\end{tabular}

\section{HASIL DAN PEMBAHASAN}

Pengolahan data rekaman seismik menggunakan program seismic imager yang terbagi menjadi 2 tahap, dimana tahap pertama menggunakan software Surface Wave Analysis Wizard dan tahap kedua menggunakan software WaveEq (Surface Wave Analysis). Software Surface Wave Analysis Wizard berfungsi untuk melakukan pickwin dan membangun kurva dispersi sedangkan WaveEq (Surface Wave Analysis) digunakan untuk membangun model awal struktur kecepatan gelombang sekunder di bawah permukaan. Berikut ini adalah hasil pengolahan data yang telah diperoleh pada saat pengukuran, dapat dilihat pada Gambar 1 sampai Gambar 12.

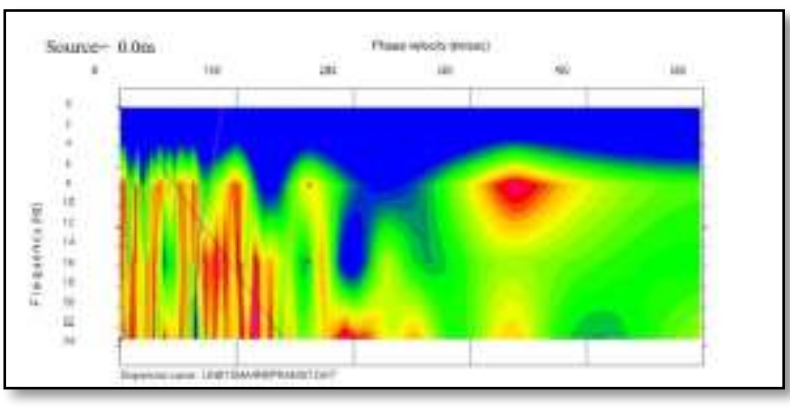

Gambar 1. Kurva dispersi pada lapangan SMA 4
Gambar 1 merupakan kurva dispersi yang menunjukkan hubungan antara frekuensi dan kecepatan pada Lapangan SMA 4. Selanjutnya dilakukan proses inversi diperoleh profil kecepatan gelombang geser seperti pada Gambar 2.

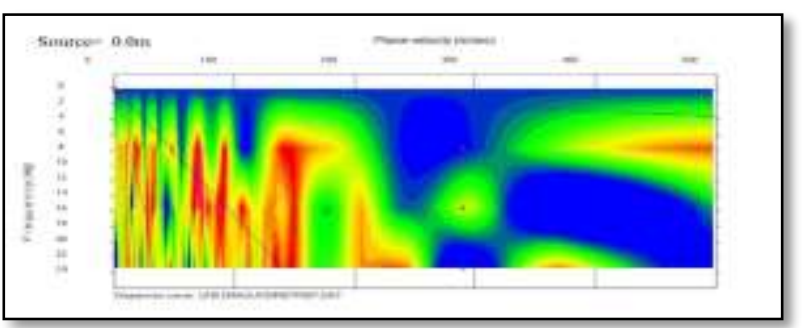

Gambar 2. Kurva dispersi pada lapangan mesjid agung

Berdasarkan profil kecepatan gelombang geser ini pula diketahui struktur batuan bawah permukaan pada Lapangan SMA 4 dapat dilihat pada Tabel 2.

Tabel 2. Struktur Batuan Bawah Permukaan Berdasarkan Nilai Kecepatan Gelombang Geser dan Kedalaman Lokasi Penelitian.

\begin{tabular}{|c|c|c|c|}
\hline Lokasi & Vs & Kedalaman & Lapisan Batuan \\
\hline & \pm 165 & $0 \mathrm{~m}-7 \mathrm{~m}$ & Aluvium \\
$\mathrm{m} / \mathrm{s}$ & & \\
\cline { 2 - 4 } & \pm 325 & $7 \mathrm{~m}-17 \mathrm{~m}$ & Pasir Tersaturasi \\
Lapangan & $\mathrm{m} / \mathrm{s}$ & & \\
\cline { 2 - 4 } SMA 4 & \pm 500 & $17 \mathrm{~m}-32 \mathrm{~m}$ & empung Pasiran \\
& $\mathrm{m} / \mathrm{s}$ & & \\
\cline { 2 - 4 } & \pm 670 & $32 \mathrm{~m}-50 \mathrm{~m}$ & empung Pasiran \\
& $\mathrm{m} / \mathrm{s}$ & & \\
\hline
\end{tabular}

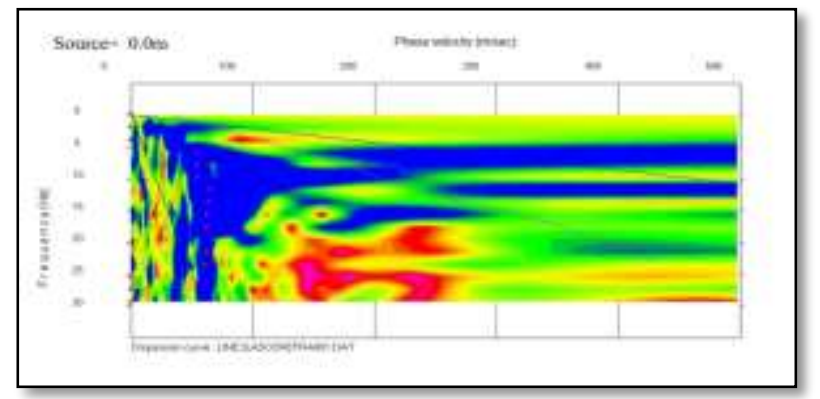

Gambar 3. Kurva dispersi pada lapangan bola lasoso

\section{Identifikasi Struktur Perlapisan Bawah Permukaan Berdasarkan Analisis Gelombang Geser Di Kecamatan Palu Barat}




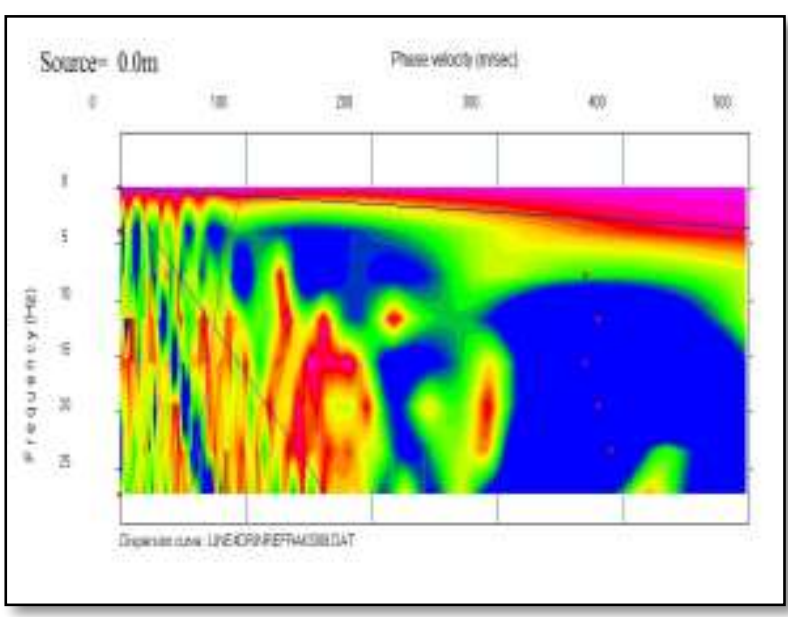

Gambar 4. Kurva dispersi pada lapangan bola durian

Gambar 3 merupakan kurva dispersi yang menunjukkan hubungan antara frekuensi dan kecepatan pada Lapangan Mesjid Agung. Selanjutnya dilakukan proses inversi diperoleh profil kecepatan gelombang geser seperti pada Gambar 4. Berdasarkan profil kecepatan gelombang geser ini pula dapat diketahui struktur batuan bawah permukaan pada Lapangan Mesjid Agung dapat dilihat pada Tabel 3.

Tabel 3. Struktur Batuan Bawah Permukaan Berdasarkan Nilai Kecepatan Gelombang Geser dan Kedalaman Lokasi Penelitian.

\begin{tabular}{|c|c|l|l|}
\hline Lokasi & Vs & Kedalaman & Lapisan Batuan \\
\hline & \pm 235 & $0 \mathrm{~m}-4 \mathrm{~m}$ & Aluvium \\
$\mathrm{m} / \mathrm{s}$ & & \\
\cline { 2 - 4 } & $\begin{array}{r} \pm 380 \\
\mathrm{~m} / \mathrm{s}\end{array}$ & $4 \mathrm{~m}-8 \mathrm{~m}$ & Pasir Tersaturasi \\
\cline { 2 - 4 } Lapangan & \pm 320 & $8 \mathrm{~m}-14 \mathrm{~m}$ & Pasir Tersaturasi \\
Mesjid & $\mathrm{m} / \mathrm{s}$ & & \\
\cline { 2 - 4 } Agung & \pm 250 & $14 \mathrm{~m}-22 \mathrm{~m}$ & Aluvium \\
& $\mathrm{m} / \mathrm{s}$ & & \\
\cline { 2 - 4 } & \pm 420 & $22 \mathrm{~m}-30 \mathrm{~m}$ & Lempung Pasiran \\
$\mathrm{m} / \mathrm{s}$ & & \\
\cline { 2 - 4 } & \pm 615 & $30 \mathrm{~m}-39 \mathrm{~m}$ & Lempung Pasiran \\
$\mathrm{m} / \mathrm{s}$ & & \\
\hline
\end{tabular}

\begin{tabular}{|c|c|c|c|}
\hline & $\begin{array}{r} \pm 35 \\
\mathrm{~m} / \mathrm{s}\end{array}$ & $39 \mathrm{~m}-50 \mathrm{~m}$ & Lempung Pasiran \\
\hline
\end{tabular}

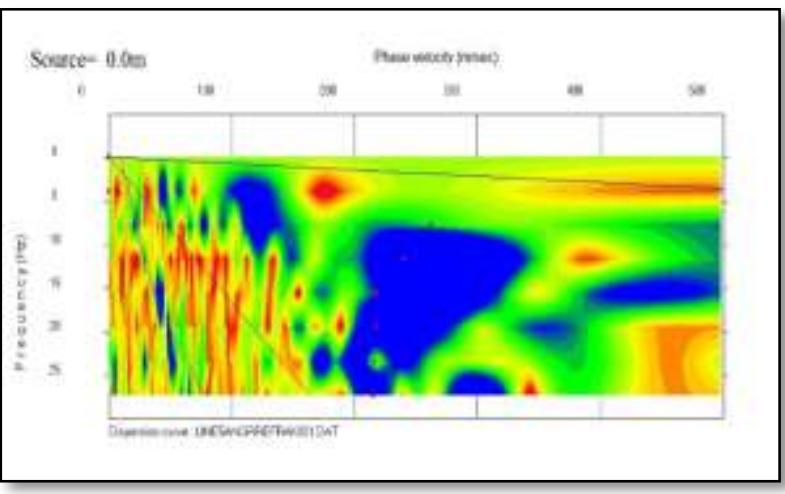

Gambar 5. Kurva dispersi pada lapangan bola anggur

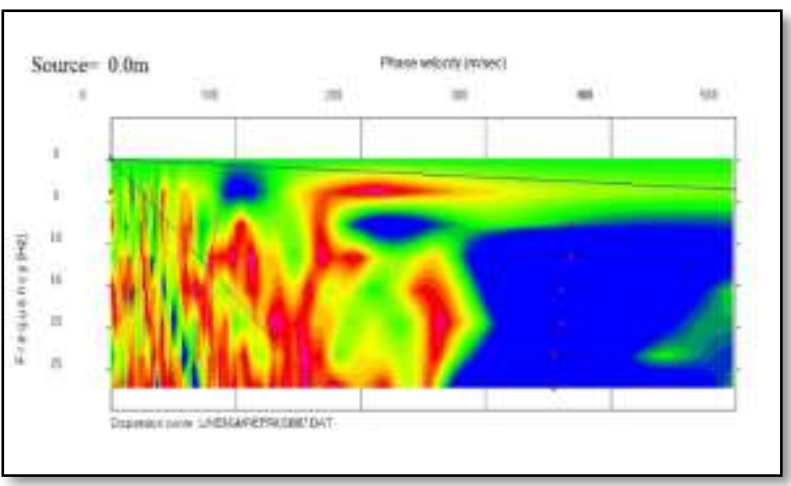

Gambar 6. Kurva dispersi pada lapangan bola gajah mada

Gambar 5 merupakan kurva dispersi yang menunjukkan hubungan antara frekuensi dan kecepatan pada Lapangan Bola Lasoso. Selanjutnya dilakukan proses inversi diperoleh profil kecepatan gelombang geser seperti pada Gambar 6. Berdasarkan profil kecepatan gelombang geser ini pula dapat diketahui struktur batuan bawah permukaan pada Lapangan Bola Lasoso dapat dilihat pada Tabel 4.

Tabel 4. Struktur Batuan Bawah Permukaan Berdasarkan Nilai Kecepatan Gelombang Geser dan Kedalaman Lokasi Penelitian.

\section{Identifikasi Struktur Perlapisan Bawah Permukaan Berdasarkan Analisis Gelombang Geser Di Kecamatan Palu Barat}




\begin{tabular}{|c|c|c|c|}
\hline Lokasi & Vs & $\underset{n}{\text { Kedalama }}$ & Lapisan Batuan \\
\hline \multirow{9}{*}{$\begin{array}{c}\text { Lapangan } \\
\text { Bola } \\
\text { Lasoso }\end{array}$} & $\begin{array}{l} \pm 135 \\
\mathrm{~m} / \mathrm{s}\end{array}$ & $0 m-3 m$ & Aluvium \\
\hline & $\begin{array}{l} \pm 350 \\
\mathrm{~m} / \mathrm{s}\end{array}$ & $3 m-7 m$ & Pasir Tersaturasi \\
\hline & $\begin{array}{l} \pm 100 \\
\mathrm{~m} / \mathrm{s}\end{array}$ & $7 m-10 m$ & Aluvium \\
\hline & $\begin{array}{l} \pm 350 \\
\mathrm{~m} / \mathrm{s}\end{array}$ & $10 m-15 m$ & Pasir Tersaturasi \\
\hline & $\begin{array}{l} \pm 235 \\
\mathrm{~m} / \mathrm{s}\end{array}$ & $15 \mathrm{~m}-22 \mathrm{~m}$ & Aluvium \\
\hline & $\begin{array}{l} \pm 195 \\
\mathrm{~m} / \mathrm{s} \\
\end{array}$ & $22 m-28 m$ & Aluvium \\
\hline & $\begin{array}{c} \pm 390 \\
\mathrm{~m} / \mathrm{s}\end{array}$ & $28 m-34 m$ & Pasir Tersaturasi \\
\hline & $\begin{array}{c} \pm 565 \\
\mathrm{~m} / \mathrm{s}\end{array}$ & $34 m-42 m$ & Lempung Pasiran \\
\hline & $\begin{array}{c} \pm 515 \\
\mathrm{~m} / \mathrm{s}\end{array}$ & $42 \mathrm{~m}-50 \mathrm{~m}$ & Lempung Pasiran \\
\hline
\end{tabular}

Lapangan Bola Durian. Selanjutnya dilakukan proses inversi diperoleh profil kecepatan gelombang geser seperti pada Gambar 8. Berdasarkan profil kecepatan gelombang geser ini pula dapat diketahui struktur batuan bawah permukaan pada Lapangan Bola Durian dapat dilihat pada Tabel 5.

Tabel 5. Struktur Batuan Bawah Permukaan Berdasarkan Nilai Kecepatan Gelombang Geser dan Kedalaman Lokasi Penelitian.

\begin{tabular}{|c|l|l|l|}
\hline Lokasi & Vs & Kedalaman & Lapisan Batuan \\
\hline \multirow{4}{*}{$\begin{array}{c}\text { Lapangan } \\
\text { Bola }\end{array}$} & $\begin{array}{l} \pm 335 \\
\mathrm{~m} / \mathrm{s}\end{array}$ & $0 \mathrm{~m}-4 \mathrm{~m}$ & Pasir Tersaturasi \\
\cline { 2 - 4 } Durian & $\begin{array}{l} \pm 470 \\
\mathrm{~m} / \mathrm{s}\end{array}$ & $4 \mathrm{~m}-10 \mathrm{~m}$ & Lempung Pasiran \\
\cline { 2 - 4 } & $\begin{array}{l} \pm 395 \\
\mathrm{~m} / \mathrm{s}\end{array}$ & $10 \mathrm{~m}-18 \mathrm{~m}$ & Lempung Pasiran \\
\cline { 2 - 4 } & $\begin{array}{l} \pm 475 \\
\mathrm{~m} / \mathrm{s}\end{array}$ & $27 \mathrm{~m}-38 \mathrm{~m}$ & Lempung Pasiran \\
\cline { 2 - 4 } & $\begin{array}{l} \pm 595 \\
\mathrm{~m} / \mathrm{s}\end{array}$ & $38 \mathrm{~m}-50 \mathrm{~m}$ & Lempung Pasiran \\
\hline
\end{tabular}

Gambar 7. Profil kecepatan gelombang geser pada lapangan SMA 4
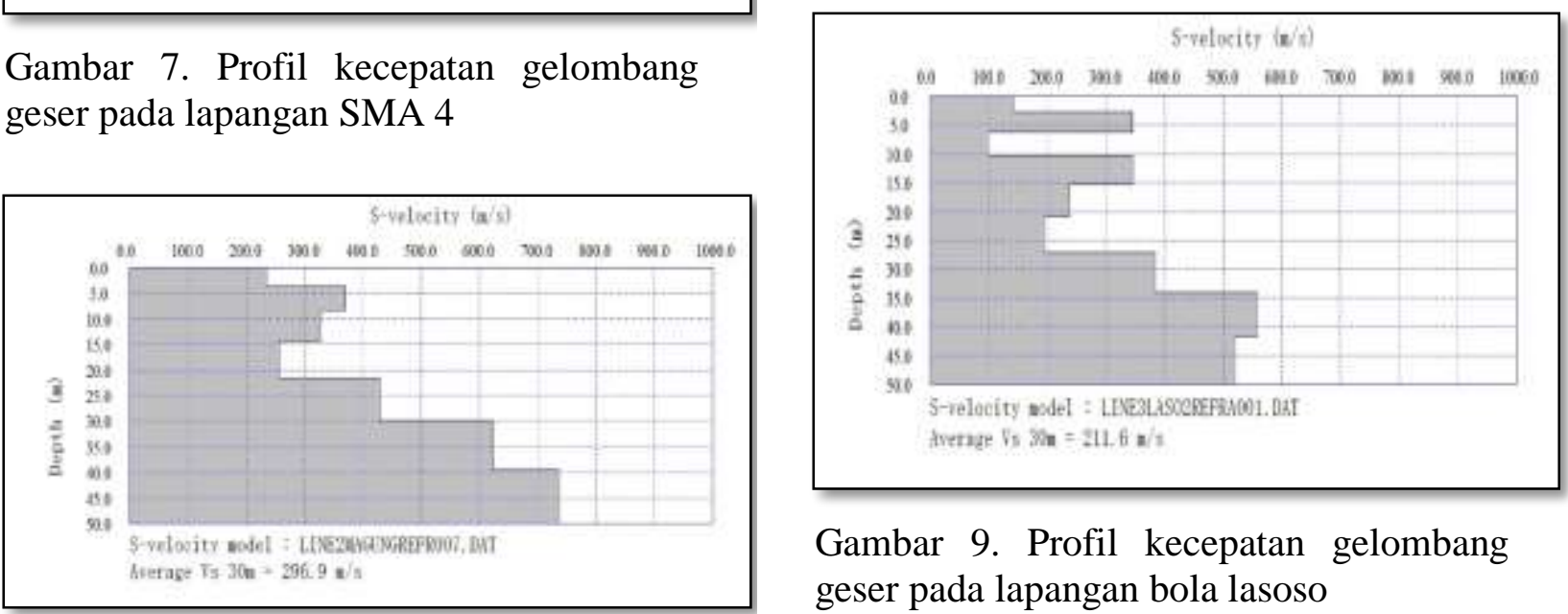

Gambar 9. Profil kecepatan gelombang geser pada lapangan bola lasoso

Gambar 8. Profil kecepatan gelombang geser pada lapangan mesjid agung

Gambar 7 merupakan kurva dispersi yang menunjukkan hubungan antara frekuensi dan kecepatan pada

\section{Identifikasi Struktur Perlapisan Bawah Permukaan Berdasarkan Analisis Gelombang Geser Di Kecamatan Palu Barat}




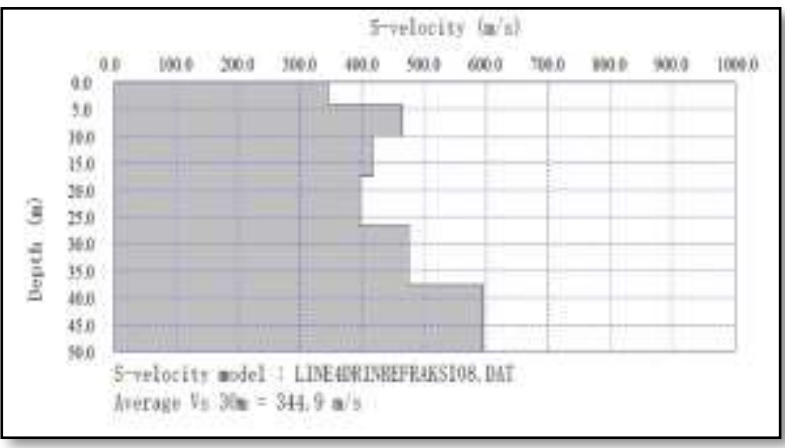

Gambar 10. Profil kecepatan gelombang geser pada lapangan bola durian

Gambar 9 merupakan kurva dispersi yang menunjukkan hubungan antara frekuensi dan kecepatan pada Lapangan Bola Anggur. Selanjutnya dilakukan proses inversi diperoleh profil kecepatan gelombang geser seperti pada Gambar 10. Berdasarkan profil kecepatan gelombang geser ini pula dapat diketahui struktur batuan bawah permukaan pada Lapangan Bola Anggur dapat dilihat pada Tabel 6.

Tabel 6. Struktur Batuan Bawah Permukaan Berdasarkan Nilai Kecepatan Gelombang Geser dan Kedalaman Lokasi Penelitian.

\begin{tabular}{|c|l|l|c|}
\hline Lokasi & Vs & Kedalaman & $\begin{array}{c}\text { Lapisan } \\
\text { Batuan }\end{array}$ \\
\hline & \pm & $0 \mathrm{~m}-7 \mathrm{~m}$ & Aluvium \\
& 215 & & \\
& $\mathrm{~m} / \mathrm{s}$ & & \\
\cline { 2 - 4 } Lapangan & \pm & $7 \mathrm{~m}-17 \mathrm{~m}$ & Aluvium \\
Bola & 290 & & \\
Anggur & $\mathrm{m} / \mathrm{s}$ & & \\
\cline { 2 - 4 } & \pm & $7 \mathrm{~m}-32 \mathrm{~m}$ & Pasir \\
& 385 & & Tersaturasi \\
& $\mathrm{m} / \mathrm{s}$ & & \\
\cline { 2 - 4 } & \pm & $32 \mathrm{~m}-50 \mathrm{~m}$ & Lempung \\
& 670 & & Pasiran \\
& $\mathrm{m} / \mathrm{s}$ & & \\
\hline
\end{tabular}

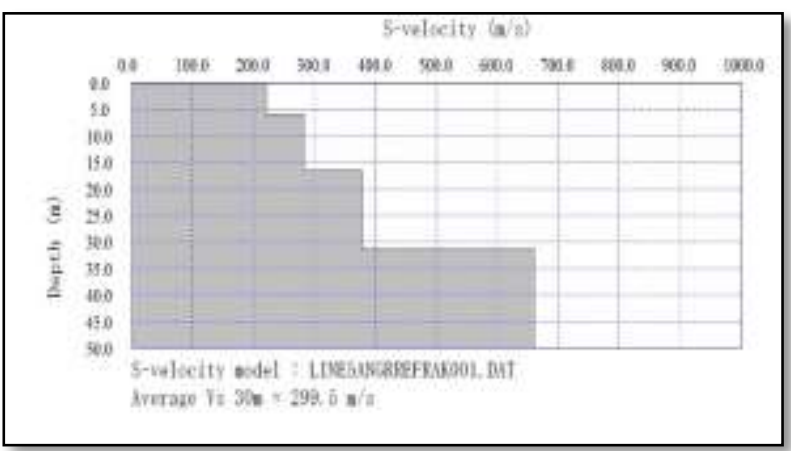

Gambar 11. Profil kecepatan gelombang geser pada lapangan bola anggur

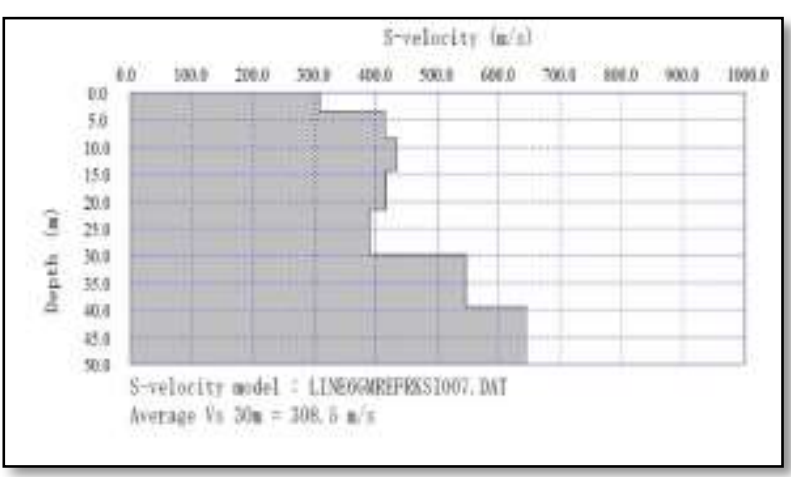

Gambar 12. Profil kecepatan gelombang geser pada lapangan bola anggur

Gambar 11 merupakan kurva dispersi yang menunjukkan hubungan antara frekuensi dan kecepatan pada Lapangan Bola Gajah Mada. Selanjutnya dilakukan proses inversi diperoleh profil kecepatan gelombang geser seperti pada Gambar 12. Berdasarkan profil kecepatan gelombang geser ini pula dapat diketahui struktur batuan bawah permukaan pada Lapangan Bola Gajah Mada dapat dilihat pada Tabel 7.

\section{Identifikasi Struktur Perlapisan Bawah Permukaan Berdasarkan Analisis Gelombang Geser Di Kecamatan Palu Barat}


Tabel 7. Struktur Batuan Bawah Permukaan Berdasarkan Nilai Kecepatan Gelombang Geser dan Kedalaman Lokasi Penelitian.

\begin{tabular}{|c|c|c|c|}
\hline Lokasi & Vs & Kedalaman & Lapisan Batuan \\
\hline \multirow{4}{*}{$\begin{array}{c}\text { Lapangan } \\
\text { Bola } \\
\text { Gajah } \\
\text { mada }\end{array}$} & $\begin{array}{r} \pm 305 \\
\mathrm{~m} / \mathrm{s}\end{array}$ & $0 m-4 m$ & Aluvium \\
\hline & $\begin{array}{l} \pm 41 \\
0 \\
\mathrm{~m} / \mathrm{s}\end{array}$ & $4 m-8 m$ & $\begin{array}{l}\text { Lempung } \\
\text { Pasiran }\end{array}$ \\
\hline & $\begin{array}{l} \pm 42 \\
5 \\
\mathrm{~m} / \mathrm{s}\end{array}$ & $8 \mathrm{~m}-14 \mathrm{~m}$ & $\begin{array}{l}\text { Lempung } \\
\text { Pasiran }\end{array}$ \\
\hline & $\begin{array}{l} \pm 41 \\
0 \\
\mathrm{~m} / \mathrm{s}\end{array}$ & $14 \mathrm{~m}-22 \mathrm{~m}$ & $\begin{array}{l}\text { Lempung } \\
\text { Pasiran }\end{array}$ \\
\hline & $\begin{array}{l} \pm 39 \\
5 \\
\mathrm{~m} / \mathrm{s}\end{array}$ & $22 m-30 m$ & $\begin{array}{l}\text { Pasir } \\
\text { Tersaturasi }\end{array}$ \\
\hline & $\begin{array}{l} \pm 54 \\
0 \\
\mathrm{~m} / \mathrm{s}\end{array}$ & $\begin{array}{l}30 m-39 \\
m\end{array}$ & $\begin{array}{l}\text { Lempung } \\
\text { Pasiran }\end{array}$ \\
\hline & $\begin{array}{l} \pm 64 \\
0 \\
\mathrm{~m} / \mathrm{s}\end{array}$ & $\begin{array}{ccc}39 & m & -50 \\
m & & \end{array}$ & $\begin{array}{l}\text { Lempung } \\
\text { Pasiran }\end{array}$ \\
\hline
\end{tabular}

Model awal diestimasi berdasarkan gelombang permukaan untuk mendapatkan nilai kecepatan fase gelombang permukaan sebagai fungsi frekuensi, sehingga didapatkan nilai kesalahan. Nilai kesalahan akan menentukan apakah perlu dilakukan iterasi atau tidak dan inversi akan selesai. Apabila nilai kesalahan lebih besar, maka dilakukan perhitungan kecepatan gelombang permukaan yang baru untuk menghasilkan kesalahan yang lebih rendah sampai mendapatkan nilai kesalahan yang diinginkan.
Hasil estimasi nilai kecepatan gelombang geser pada lokasi pertama berkisar antara $165 \mathrm{~m} / \mathrm{s}$ sampai $670 \mathrm{~m} / \mathrm{s}$, untuk lokasi kedua berkisar antara $235 \mathrm{~m} / \mathrm{s}$ sampai $735 \mathrm{~m} / \mathrm{s}$, untuk lokasi ketiga berkisar antara $100 \mathrm{~m} / \mathrm{s}$ sampai $565 \mathrm{~m} / \mathrm{s}$, untuk lokasi keempat berkisar antara 335 $\mathrm{m} / \mathrm{s}$ sampai $595 \mathrm{~m} / \mathrm{s}$, untuk lokasi kelima berkisar antara $215 \mathrm{~m} / \mathrm{s}$ sampai $670 \mathrm{~m} / \mathrm{s}$, untuk lokasi keenam berkisar antara 305 $\mathrm{m} / \mathrm{s}$ sampai $640 \mathrm{~m} / \mathrm{s}$. Nilai kecepatan gelombang geser tersebut menunjukan bahwa pada lokasi Lapangan SMA 4 didominasi oleh batuan aluvium, pasir tersaturasi dan lempung pasiran, begitu juga pada lokasi Lapangan Mesjid Agung, Lapangan Bola Lasoso, Lapangan Bola Durian, Lapangan Bola Anggur dan Lapangan Bola Gajah Mada masih didominasi oleh batuan aluvium, pasir tersaturasi dan lempung pasiran.

Dari hasil estimasi nilai kecepatan gelombang geser yang didapatkan di lokasi penelitian sangat kecil yaitu $100 \mathrm{~m} / \mathrm{s}$. Hal ini disebabkan oleh porositas untuk batuan aluvium, lempung pasiran dan pasir tersaturasi lebih besar dari pada porositas batuan lainnya dan besarnya kecepatan perambatan gelombang geser selalu berbanding terbalik dengan porositas suatu batuan.

\section{Identifikasi Struktur Perlapisan Bawah Permukaan Berdasarkan Analisis Gelombang Geser Di Kecamatan Palu Barat}




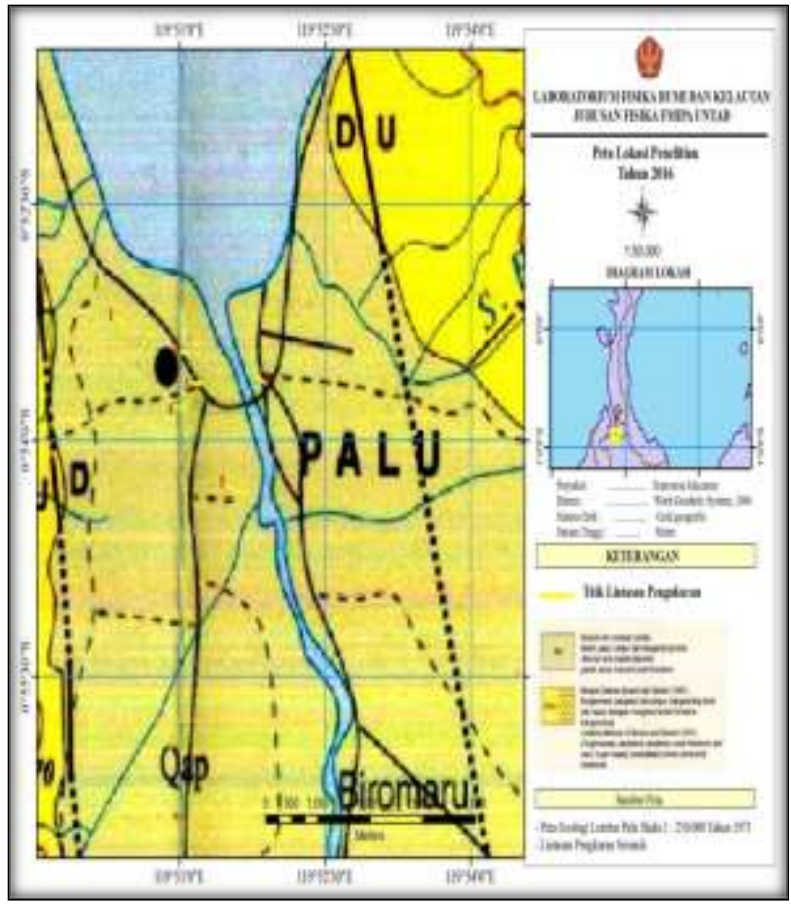

Gambar 13. Peta geologi lokasi penelitian

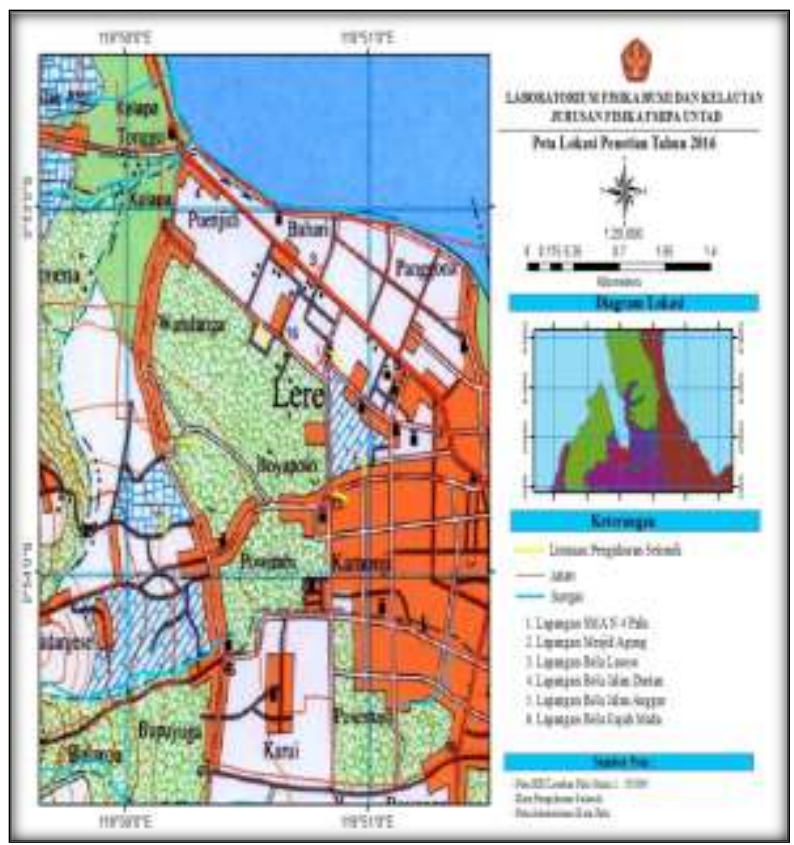

Gambar 14. Peta lokasi penelitian (Sumber: Peta RBI Lembar Palu, Skala 1: 50.000)

\section{UCAPAN TERIMA KASIH}

Penulis ucapkan terima kasih kepada teman-teman dan semua pihak yang telah terlibat dalam pengambilan data dan yang sudah membantu memfasilitasi penulis dengan memberikan izin dalam pengambilan data di lapangan.

\section{DAFTAR PUSTAKA}

Abdullah, 2005, Sesar Palu Koro, Palu, HU. Radar Sulteng: 28 Januari 2005.

Susy, K., Ariestianty, Raihan, T., Khairul, A., Mohd, Nayan., dan Zamri, C., 2009, Penenteuan Modulus Geser Tanah Menggunakan Metode Analisis Multi-Channel Gelombang Permukaan, jurnal Ilmiah Semesta Teknika,Vol. 12, No 2, Diakses tanggal 11 Februari 2013 dari http:umy.ac.id

Uswatun, C., 2012, Studi Awal Tentang Model Kecepatan Gelombang P dan Gelombang $S$ Untuk Mengetahui Struktur Geologi dengan Algoritma Genetika, Makalah Tugas Akhir Simulasi Sistem Fisis II UNESA, Surabaya. Diakses tanggal 11 Februari 2013 dari http://110.139.12.18/web/webuswah/TA-SSF\%20II.pdf

Widodo, P., 2012, Seismologi Teknik \& Rekayasa Kegempaan, Universitas Islam, Yogyakarta. 